$10-8-2021$

\title{
Dossier: The Stateless Rohingya-Practical Consequences of Expulsion
}

Fiza Lee-Winter

Ruhr-Universität Bochum

Tonny Kirabira

University of Portsmouth

Follow this and additional works at: https://digitalcommons.usf.edu/gsp

\section{Recommended Citation}

Lee-Winter, Fiza and Kirabira, Tonny (2021) "Dossier: The Stateless Rohingya-Practical Consequences of Expulsion," Genocide Studies and Prevention: An International Journal: Vol. 15: Iss. 2: 3-9.

DOI:

https://doi.org/10.5038/1911-9933.15.2.1863

Available at: https://digitalcommons.usf.edu/gsp/vol15/iss2/4

This Dossier is brought to you for free and open access by the Open Access Journals at Digital Commons @ University of South Florida. It has been accepted for inclusion in Genocide Studies and Prevention: An International Journal by an authorized editor of Digital Commons @ University of South Florida. For more information, please contact digitalcommons@usf.edu. 


\title{
Dossier: The Stateless Rohingya-Practical Consequences of Expulsion
}

\author{
Fiza Lee-Winter \\ Ruhr-Universität Bochum \\ Bochum, Germany \\ Tonny Kirabira \\ University of Portsmouth \\ Portsmouth, England
}

\section{Introduction ${ }^{1}$}

In October 2013, the UN High Commissioner of Refugees called for the "total commitment of the international community to end statelessness," with the ultimate goal of ending statelessness within 10 years, thus resulting in the establishment of Global Action Plan to End Statelessness: 2014-2024, providing states with a guiding framework of 10 Actions in a worldwide effort to ultimately end statelessness. Action 7 of the Global Action Plan calls on States to "ensure birth registration for the prevention of statelessness," ${ }^{2}$ as birth certificates provide key information that assists children to confirm or acquire nationality. ${ }^{3}$ This dossier presents the practical consequences of expulsion and discusses the imperative need for the Association of Southeast Asian Nations (ASEAN) states-collectively as a region-to take steps in fulfilling Action 7 of the Global Action Plan as part of their existing efforts in order to enhance the protection of refugee children. ${ }^{4}$

The focus on ASEAN is imperative due to its orthodox practice of collective-based decision making, but also evolving approaches towards atrocity prevention and integration of human rights norms within member states. ${ }^{5}$ Referring to the Rohingya refugee crisis in particular, this dossier also explores ways in which birth registration impacts the status of Rohingya refugee children in this region, without which these stateless children are placed at greater risk of becoming victims to child trafficking.

With over one million Rohingya refugees escaping persecution in Cox's Bazar, Bangladesh, and many more having been displaced since the 2012-according to UNHCR, 741,947 Rohingya refugees have fled their homes in Rakhine state in Myanmar into neighboring Bangladesh since August 20176-this issue merits special attention. As victims of collective violence, the Rohingyas not only face direct attacks to their persons (bodily harm) and their properties; ${ }^{7}$ the effects from experiencing such violence can be far-reaching and with adverse

\footnotetext{
${ }^{1}$ The views expressed in this Dossier belong solely to the authors. Due to their ongoing nature, Dossiers do not undergo the double-blind peer review process.

2 UN High Commissioner for Refugees (UNHCR), “Global Action Plan to End Statelessness: 2014-2024," (Geneva: Division of International Protection, UNCHR, 2017), 2, accessed 30 August 2021, https://www.unhcr.org/ $\underline{54621 b f 49 . h t m l}$.

3 UNHCR, "Ensuring Birth Registration for the Prevention of Statelessness," (UNCHR, 2017), 1, accessed August 30, 2021, https://www.unhcr.org/ke/wp-content/uploads/sites/2/2017/11/Good-Practices-Paper-on-EnsuringBirth-Registration-for-the-Prevention-of-Statelessness.pdf.

4 ASEAN is an intergovernmental economic union established on August 8, 1967, comprising 10 member states in Southeast Asia, namely Brunei, Cambodia, Indonesia, Laos, Malaysia, Myanmar, Philippines, Singapore, Thailand and Vietnam. See "About ASEAN," ASEAN, n.d., accessed October 8, 2021, https://asean.org/about-us.

${ }^{5}$ David A. Frank, "The Reduction of Mass Atrocity Crimes in East Asia: The Evolving Norms of ASEAN's Prevention Mechanisms," Genocide Studies and Prevention 11, no. 3 (2018), 105.

${ }^{6}$ For a more elaborate analysis, see UNHCR, "Refugee Movements in South-East Asia 2018-June 2019," (UNHCR, October 1, 2019) 2, accessed 30 August 2021, https:/ / www.unhcr.org/5d91e2564.pdf. 7 Ibid.
}

Fiza Lee-Winter and Tonny Kirabira. "Dossier: The Stateless Rohingya-Practical Consequences of Expulsion." Genocide Studies and Prevention 15, no. 2, 3-9. https://doi.org/10.5038/1911-9933.15.2.1863.

(c) 2021 Genocide Studies and Prevention. 
consequences, particularly to their health and well-being. ${ }^{8}$ In addition, the Rohingyas' vulnerability are intensified simply by being stateless.

Before delving into the gist of the dossier, it is important to draw a distinction between de jure and de facto statelessness. While de jure statelessness refers to the formal legal aspects of citizenship and rights e.g. issuance of birth certificates, de facto statelessness relates to the more practical situations where refugees do not have any protections in the host states. ${ }^{9}$ This dossier thus presents an argument for the de jure recognition of refugee children under the host states' laws, through the practice of birth registration.

Challenges associated with children's statelessness and lack of legal status vary for each country, depending on the national laws. However, looking beyond the practical challenges, empirical research reveals profound connections between legal identity documentation, birth registration, and human rights protection. ${ }^{10}$ More specifically, the negative impact stemming from the lack of birth registration and statelessness on the economic and social rights of children ${ }^{11}$ should not be understated-and such trends beg for more attention, whether scholarly or in-practice, especially in contemporary contexts like the Rohingya crisis.

\section{Linked Vulnerabilities}

Why the extra focus on the Rohingyas? The first reason is an obvious one-the majority of refugees moving through the Southeast Asian (SEA) region are stateless Rohingyas. ${ }^{12}$ Emerging scholarship on Rohingya statelessness reveal challenges of legal identity in countries like India, ${ }^{13}$ and Rohingya refugees themselves are considered to be "the most marginalized and persecuted section of people in the world."14 But what is more unsettling is their extreme vulnerability in the SEA region. Reports in past years reveal that a host of Rohingya refugees have become victims of human trafficking and smuggling into countries like Thailand and Malaysia. ${ }^{15}$ Being caught in a protracted conflict, the Rohingyas suffer serious limitations on their basic human rights, not only in their country of origin, but also along the way as they make their journey to relative safety. Living under such dire conditions, the Rohingya refugees become extremely vulnerable to exploitation by traffickers. ${ }^{16}$

In the case of Rohingya children, the situation is much more dire as they become targets by child traffickers for forced labor, prostitution, and slavery under the guise of "better opportunities" for work abroad. While some children were at first thought to be kidnapped

8 UNHCR, Refugee Movements, 2.

${ }^{9}$ Hugh Massey, Legal and Protection Policy Research Series: UNHCR and De Facto Statelessness (Geneva: Division of International Protection, UNHCR, April 2010), 3, accessed July 2, 2021, https://www.unhcr.org/en-us/protection/ globalconsult/4bc2ddeb9/16-unhcr-de-facto-statelessness-hugh-massey.html; Aaron Hale and Fredline M'Cormack-Hale, "Statelessness, Nationality, and Citizenship in Sierra Leone," Journal of Global South Studies 35, no. 2 (2018), 311.

${ }^{10}$ Caroline Vandenabeele, "To Register or Not to Register?: Legal Identity, Birth Registration, and Inclusive Development," in Children Without a State: A Global Human Rights Challenge, ed. Jacqueline Bhabha (Cambridge: The MIT Press, 2011), 307-330.

${ }^{11}$ Jacqueline Bhabha, "From Citizen to Migrant: The Scope of Child Statelessness in the Twenty-First Century," in Children Without a State: A Global Human Rights Challenge, ed. Jacqueline Bhabha (Cambridge: The MIT Press Cambridge, 2011), 1-42.

12 UNHCR, Refugee Movements.

13 Tejal Khanna, "Rohingyas and the (Il)Legal Quest for an Indian Identity," Statelessness \& Citizenship Review 2, no. 2 (2020), 342, accessed October 8, 2021, https://statelessnessandcitizenshipreview.com/index.php/journal/article/ view/221/109.

14 Kudrat-E-Khuda (Babu), "The Impacts and Challenges to Host Country Bangladesh Due to Sheltering the Rohingya Refugees," Cogent Social Sciences 6, no. 1 (2020), 2.

${ }^{15}$ Ranyta Yusran, "The ASEAN Convention Against Trafficking in Persons: A Preliminary Assessment," Asian Journal of International Law 8, no. 1 (2018), 258.

16 The ASEAN Post Team, "ASEAN's Human Trafficking Woes," The ASEAN Post, May 11, 2020, accessed August 20, 2021, https:// theaseanpost.com/article/aseans-human-trafficking-woes. 
(missing persons cases), in actual fact, the situation is much more insidious ${ }^{17}$ - they have been lured out of their camps and into labor and prostitution. ${ }^{18}$ Further, according to Chakraborty and Bhabha, the appalling experiences of the stateless Rohingyas in SEA during the COVID-19 pandemic demonstrate the need for formal legal recognition of refugees ${ }^{19}$-for stateless children, major concerns relate to limited access to food, education, an increase in child marriage and labor ${ }^{20}$ without which would result in adverse consequences and impacts, due to their expulsion and their default statelessness.

\section{The Right of the Child to Birth Registration}

Stein identifies administrative practices of birth registration among the contemporary causes of child statelessness. ${ }^{21}$ Although birth registration does not guarantee a right to citizenship, it lays a foundation for the obtaining of nationality, but also opens up channels for the enjoyment of human rights. ${ }^{22}$ Crucially, a human rights-based approach is necessary in dealing with child statelessness.

From an international human rights perspective, birth registration can be linked with the right to acquire a nationality under the United Nations Convention on the Rights of the Child (CRC): "The child shall be registered immediately after birth and shall have the right from birth to a name, the right to acquire a nationality and. as far as possible, the right to know and be cared for by his or her parents." 23

Additionally, there are state obligations under the CRC: "States Parties shall ensure the implementation of these rights in accordance with their national law and their obligations under the relevant international instruments in this field, in particular where the child would otherwise be stateless." 24 However, we ought to remain cognizant of the deferring state practices in relation to citizenship laws and birth registration. As Stein points out, divergent domestic systems arise, limiting the protection of stateless people, including children. ${ }^{25}$

Out of all the ASEAN states hosting Rohingya refugees, only Cambodia and the Philippines are signatories to the 1951 Refugee Convention. As a result of this lack of international legal obligation, countries like Thailand, Indonesia, and Malaysia (affected countries) are observed to apply exclusionary policies against Rohingya refugees. ${ }^{26}$ But since we are extending this discussion to look at refugee and stateless children, from a normative perspective, all the 10 ASEAN Member States have signed and ratified the CRC, which provides a firm foundation for the protection of undocumented and stateless children. ${ }^{27}$ Against the background of this legal framework, we are convinced that birth registration can be used as a

17 Leif Coorlim and Thomas Page, "Stolen Son: The Child Traffickers Preying on the Rohingya," CNN, August 31, 2019, accessed August 29, 2021, https://edition.cnn.com/2019/08/31/asia/stolen-son-rohingya-coxs-bazar-intl/ index.html. Watch video embedded in citation for further information on human trafficking and children trafficking of the Rohingyas in Cox's Bazar, Bangladesh.

18 "The Rohingya Children Trafficked for Sex," BBC, March 20, 2018, accessed October 8, 2021, https://www.bbc.com/ news/world-asia-43469043.

19 Roshni Chakraborty and Jacqueline Bhabha, "Fault Lines of Refugee Exclusion: Statelessness, Gender, and COVID-19 in South Asia," Health \& Human Rights: An International Journal 23, no. 1 (2021), 237.

${ }^{20}$ Ibid.

${ }^{21}$ Jill Stein, "The Prevention of Child Statelessness at Birth: The UNCRC Committee's Role and Potential," International Journal of Children's Rights 24, no. 3 (2016), 599, 619.

22 Ibid., 618

${ }^{23}$ UN General Assembly, Convention on the Rights of the Child, 20 November 1989, United Nations, Treaty Series, vol. 1577, Art. 7(1).

${ }^{24}$ Ibid., Art. 7(2).

${ }^{25}$ Stein, Prevention of Child Statelessness, 602.

26 A. K. M. Ahsan Ullah, “Rohingya Crisis in Myanmar: Seeking Justice for the 'Stateless,'” Journal of Contemporary Criminal Justice 32, no. 3 (2016), 285.

27 ASEAN, "Children in ASEAN: 30 Years of the Convention on the Rights of the Child," (ASEAN and UNICEF, 2019), 11, accessed July 2, 2021, https:/ / reliefweb.int/sites/reliefweb.int/ files/resources/Children\%20in\%20ASEAN.pdf. 
tool in protecting the rights of refugee and stateless children in the region, including the Rohingyas.

\section{Obstacles to Birth Registration: The Case of Thailand}

As a state hosting one of the largest stateless populations in the world, "according to data from the Ministry of Interior in 2019, Thailand is home to more than 539,000 stateless persons, among which around 206,000 or 40 per cent are children." 28

Under Thailand's Civil Registration Act, which was revised and implemented in September 2010, "all children born in the country are entitled to birth registration even if their parents are not Thai nationals." 29 Thailand considers this to be "one of the key conditions for the prevention of human trafficking and statelessness, and ensuring access to basic rights of children in various fields, especially education and health services" 30 and has extended the access to birth registration for "all children born in Thailand, including cross-border migrants and ethnic populations." 31

However, almost a decade later, the impacts of the legislation still remain unclear. This is largely due to challenges related to the situation of access to birth registration of children, further compounded by a lack of data on the actual number of the sub-groups living in Thailand at any given time. ${ }^{32} \mathrm{~A}$ recent quantitative study, conducted by the Legal Research and Development Centre at the Faculty of Law in Chiang Mai University with support from the European Union (EU) and UNICEF, indicated that the "challenge remains largely in translating policy into practice especially at the local level...[which include] inadequate human and financial resources, complex and overburdened procedures and negative attitudes among officials toward stateless families." 33 This corroborated the findings of a previous study which also indicated a lack of awareness among parents on how to access birth registration. ${ }^{34}$ Despite this setback, the data did indicate that some parents wanted "the child to have Thai health and education rights" as a reason for why they complied with the birth registration law, alluding to their understanding of the importance of birth registration as a right and an equity improvement strategy. ${ }^{35}$

\section{Optimizing Legislation to Enhance State Practice}

In recent years, ASEAN states have used legal instruments like the Convention against Trafficking in Persons especially in Women and Children (ACTIP) to guide state practice. ${ }^{36} \mathrm{~A}$

\footnotetext{
28 "Progress Must be Accelerated to End the Cycle of Statelessness: EU and UNICEF," UNICEF Thailand, April 9, 2021, accessed August 30, 2021, https://www.unicef.org/thailand/press-releases/progress-must-be-accelerated-endcycle-statelessness-eu-and-unicef.

${ }^{29}$ Vivian Tan, "In Thailand, Birth Registration Gives Refugee Babies a Good Start in Life," UNCHR, September 24, 2012, accessed August 30, 2021, https://www.unhcr.org/news/latest/2012/9/50604a959/thailand-birth-registrationgives-refugee-babies-good-start-life.html.

30 Chalermpol Chamchan, Kanya Apipornchaisakul and Phongsak Muensakda, "An Assessment of Access to Birth Registration among Migrant Children: The Quantitative Study," (Salaya: Mahidol University, Thailand, June 2021), 1, accessed October 8, 2021, https:/ / www.unicef.org/thailand/media/6456/file/BR\%20Assessment.pdf.

${ }^{31}$ Ibid.

32 Ibid.

33 UNICEF Thailand, Progress Must be Accelerated. Link to the study "Invisible Lives: 48 Years of the Situation of Stateless Children in Thailand (1972-2020)" is in the press release. The final report has been published in the Thai language.

${ }^{34}$ Chamchan et al., Assessment of Access to Birth Registration, 55-56; see also Joint submission of: Franciscans International (FI) and Marist International Solidarity Foundation (FMSI) for the Universal Periodic Review (UPR) of Thailand in 2016, paras. 8-12, accessed August 29, 2021, https:// fmsi.ngo/wp-content/uploads/2019/09/2016.UPR-ThailandFI-FMSI-EN.pdf.

35 On the importance of equity, see Harry Jones, "Equity in Development: Why It is Important and How to Achieve It" (London: Overseas Development Institute, November 13, 2009), accessed October 8, 2021, https://cdn.odi.org/ media/documents/4577.pdf

36 Yusran, The ASEAN Convention.
} 
host of soft law instruments also indicate ASEAN states' commitment towards the protection of children's rights in the region. ${ }^{37}$ Whilst recognizing that one size does not necessarily fit all, birth registration should be seen as an important step to the prevention of statelessness. In the case of refugee and stateless children, being without birth registration puts these children at a higher risk of being trafficked for many reasons including forced labor, prostitution, forced or early marriages, and even recruitment as child soldiers; such are the far-reaching impacts and consequences of collective violence. Additionally, collective action by ASEAN states will help to create the necessary political will to implement the norms at the domestic level. It is important to note that political will is a vital element in the domestic enforcement and implementation of human rights, including those of vulnerable groups like the Rohingyas. 38

As a region heavily affected by human trafficking, it is in the ASEAN states' interest to develop a regional framework and adopt a workable uniform state practice on birth registration of refugee and stateless children. Such capacity building and mobilization will undoubtedly have a positive impact, not only in combatting human and child trafficking, but also to meet the commitments towards ending statelessness by 2024.

We are cognizant of the challenges of implementing top-down approaches in an era where policy and legal framers seek for more localized approaches towards refugee protection. What this commentary stresses, is the need for more attention towards stateless children by all stakeholders at both domestic and regional levels. Ultimately, addressing the situation of these vulnerable children through birth registration will also require the involvement of non-state actors like Non-Governmental Organizations (NGOs).

NGOs have the potential to influence both the adoption and implementation of the ASEAN legal framework. ${ }^{39}$ Due to the context sensitive dynamics of migration, the effective implementation of the proposed laws will necessitate the engagement of the refugee host communities about the relevance of registering refugee children. Even with the (legal and practical) challenges and obstacles associated to birth registration, we remain convinced that ASEAN states should endeavor to develop and implement a workable framework as this addresses statelessness and combatting human trafficking at the same time. Without birth registration, these stateless children are left at greater risk to fall victims to child trafficking. As such, this dossier also opens up sightlines for various socio-legal approaches to tackle the issue of statelessness as a direct response to collective violence.

\section{Bibliography}

Association of Southeast Asian Nations (ASEAN). "About ASEAN," n.d. Accessed October 8, 2021. https: / / asean.org/about-us.

ASEAN. "Children in ASEAN: 30 Years of the Convention on the Rights of the Child." ASEAN and UNICEF, 2019. Accessed July 2, 2021. https://reliefweb.int/sites/reliefweb.int/ files/resources/Children\%20in\%20ASEAN.pdf.

BBC. "The Rohingya Children Trafficked for Sex." March 20, 2018. Accessed October 8, 2021. https://www.bbc.com/news/world-asia-43469043.

Bhabha, Jacqueline. "From Citizen to Migrant: The Scope of Child Statelessness in the TwentyFirst Century." In Children Without a State: A Global Human Rights Challenge, ed. Jacqueline Bhabha, 1-42. Cambridge: The MIT Press Cambridge, 2011.

\footnotetext{
${ }^{37}$ For a more elaborate overview, see ASEAN Plan of Action for Children (1993); Hanoi Declaration on the Enhancement of Welfare and Development of ASEAN Women and Children (2010); Declaration on the Elimination of Violence Against Women and Elimination of Violence Against Children in ASEAN (2013); ASEAN Regional Plan of Action on Elimination of Violence Against Children (2016); ASEAN Declaration on Strengthening Education for Out-ofSchool Children and Youth (2016) and ASEAN Early Childhood Care, Development and Education Quality Standards (2017).

38 Frank, Reduction of Mass Atrocity Crimes in East Asia, 99.

39 Ibid., 102.
} 
Chakraborty, Roshni and Jacqueline Bhabha. "Fault Lines of Refugee Exclusion: Statelessness, Gender, and COVID-19 in South Asia." Health \& Human Rights: An International Journal 23, no. 1 (2021), 237-250.

Chamchan, Chalermpol, Kanya Apipornchaisakul, and Phongsak Muensakda. "An Assessment of Access to Birth Registration among Migrant Children: The Quantitative Study." Salaya: Mahidol University, Thailand, June 2021. Accessed October 8, 2021. https:// www.unicef.org/thailand/media/6456/ file/BR\%20Assessment.pdf.

Coorlim, Leif and Thomas Page. "Stolen Son: The Child Traffickers Preying on the Rohingya," CNN, August 31, 2019. Accessed August 29, 2021. https://edition.cnn.com/ 2019/08/31/asia/stolen-son-rohingya-coxs-bazar-intl/index.html.

Frank, David A. "The Reduction of Mass Atrocity Crimes in East Asia: The Evolving Norms of ASEAN's Prevention Mechanisms." Genocide Studies and Prevention 11, no. 3 (2018), 180199. Accessed October 8, 2021. https://digitalcommons.usf.edu/cgi/viewcontent.cgi? article $=1503 \&$ context $=$ gsp.

Hale, Aaron and Fredline M'Cormack-Hale, "Statelessness, Nationality, and Citizenship in Sierra Leone." Journal of Global South Studies 35, no. 2 (2018).

Jones, Harry. "Equity in Development: Why It is Important and How to Achieve It." London: Overseas Development Institute, November 13, 2009. Accessed October 8, 2021. https://cdn.odi.org/media/documents/4577.pdf.

Khanna, Tejal. "Rohingyas and the (Il)Legal Quest for an Indian Identity." Statelessness \& Citizenship Review 2, no. 2 (2020), 342-347. Accessed October 8, 2021. https:// statelessnessandcitizenshipreview.com/index.php/journal/article/view/221/109.

Kudrat-E-Khuda (Babu). "The Impacts and Challenges to Host Country Bangladesh Due to Sheltering the Rohingya Refugees." Cogent Social Sciences 6, no. 1 (2020), 1-16. Accessed October 8, 2021. https://www.tandfonline.com/doi/pdf/ $\underline{10.1080 / 23311886.2020 .1770943 .}$.

Massey, Hugh. Legal and Protection Policy Research Series: UNHCR and De Facto Statelessness. Geneva: Division of International Protection, UNHCR, April 2010. Accessed July 2, 2021. https://www.unhcr.org/en-us/protection/globalconsult/4bc2ddeb9/16-unhcrde-facto-statelessness-hugh-massey.html.

Stein, Jill. "The Prevention of Child Statelessness at Birth: The UNCRC Committee's Role and Potential." International Journal of Children's Rights 24, no. 3 (2016), 599-623.

Tan, Vivian. "In Thailand, Birth Registration Gives Refugee Babies a Good Start in Life." UNCHR, September 24, 2012. Accessed August 30, 2021. https://www.unhcr.org/ news / latest/2012/9/50604a959/ thailand-birth-registration-gives-refugee-babies-goodstart-life.html.

The ASEAN Post Team. "ASEAN's Human Trafficking Woes.” The ASEAN Post, May 11, 2020. Accessed August 20, 2021. https://theaseanpost.com/article/aseans-humantrafficking-woes.

Ullah, A. K. M. Ahsan. "Rohingya Crisis in Myanmar: Seeking Justice for the 'Stateless.'” Journal of Contemporary Criminal Justice 32, no. 3 (2016), 285-301.

UN General Assembly. Convention on the Rights of the Child, 20 November 1989, United Nations, Treaty Series, vol. 1577.

UN High Commissioner for Refugees (UNHCR). "Ensuring Birth Registration for the Prevention of Statelessness." Geneva: UNCHR, 2017. Accessed August 30, 2021. https://www.unhcr.org/ke/wp-content/uploads/sites/2/2017/11/Good-PracticesPaper-on-Ensuring-Birth-Registration-for-the-Prevention-of-Statelessness.pdf.

"Global Action Plan to End Statelessness: 2014-2024." Geneva: Division of International Protection, UNCHR, 2017. Accessed 30 August 2021. https:// www.unhcr.org/54621bf49.html.

" "Refugee Movements in South-East Asia 2018-June 2019." UNHCR, October 1, 2019. Accessed 30 August 2021. https:// www.unhcr.org/5d91e2564.pdf. 
UNICEF Thailand. "Progress Must be Accelerated to End the Cycle of Statelessness: EU and UNICEF." April 9, 2021. Accessed August 30, 2021. https://www.unicef.org/thailand/ press-releases/progress-must-be-accelerated-end-cycle-statelessness-eu-and-unicef.

Vandenabeele, Caroline. “To Register or Not to Register?: Legal Identity, Birth Registration, and Inclusive Development." In Children Without a State: A Global Human Rights Challenge, edited by Jacqueline Bhabha, 307-330. Cambridge: The MIT Press, 2011.

Yusran, Ranyta. "The ASEAN Convention Against Trafficking in Persons: A Preliminary Assessment." Asian Journal of International Law 8, no. 1 (2018), 258-292. 